\title{
Život Nikolaje Jevreinova
}

\author{
Jana Bartůňková
}

\section{Úvodem}

Při pátrání po tom, kdo je Nikolaj Nikolajevič Jevreinov (1879, Moskva - 1953, Paříž), není př́liš obtížné se z internetových zdrojů dozvědět, že se jedná o ruského divadelního režiséra, teoretika a historika, propagátora jakési divadelnosti. Situace v klasických zdrojích je odlišná; heslo Jevreinov se nevyskytuje snad v žádné obecně známé české (původní i přeložené) encyklopedii. Zarážející však je, že toto se týká i dostupných encyklopedií ruských. Tím hned na začátku výzkumu vyvstala elementární otázka, vycházející z potřeby vyrovnat se s nedostatkem relevantních informací; Kdo to tedy vlastně byl Nikolaj Jevreinov? Jak a kde žil, s kým se setkával a čím by měl být pro současnou generaci divadelníků a divadelních teoretiků zajímavý? Předložená biografie si klade za cíl být prvním pokusem začít na tyto otázky uspokojivě odpovídat a zároveň poskytnout výchozí bod pro budoucí výzkum skutečného Jevreinovova přínosu západnímu divadelnictví a teorii umění.

Že by mohl být Jevreinov zajímavým a důležitým i pro české myšlení o divadle, se dá usuzovat už z rejstříků prací Jindřicha Honzla a Iva Osolsobě. ${ }^{1} \mathrm{~V}$ česky psané literatuře se o Jevreinovovi výrazněji zmiňují ještě Karel Martínek a Jan Hyvnar, který o něm napsal shrnující stat’ „Jevrejnovova apologie divadelnosti“. Martínkova recepce Jevreinova je zanesena silnou vrstvou ideologického prachu, ${ }^{2}$ Honzl se zase k Jevreinovovi vyjadřuje jen asi do počátku třicátých let. ${ }^{3} \mathrm{~V}$ časopise Theatralia $(2014 / 1)$ pak vyšla kapitola

1 Iva Osolsobě spojuje s Jevreinovem především jeho teorie ostenze. Jevreinovova koncepce zdivadelnění života je přiznána jako jeden z inspiračních zdrojů Osolsoběho pozděǰsí práce (OSOLSOBĚ 2003: 43-44).

2 Ze tři Martínkových publikací k tématu najdeme pouze v jedné „bezproblémovou“ reflexi Jevreinovovy tvorby, a to v Dějinách sovětského divadla z roku 1967. Je s podivem, že o pouhý rok dříve Martínek užívá formulace typu: „Padesátiletý odstup dává možnost mnohem benevolentněji posuzovat jejich [Komissarževského a Jevreinova, pozn. $J B]$ životní omyly, které je přivedly mimo rodnou zemi [...]." (MARTÍNEK 1966: 33) $\mathrm{O}$ dvacet let později Jevreinovovi věnuje jeden z portrétů v knize zasvěcené ruským divadelním modernistům a sovětským avantgardistům, Jevreinovův obraz je však nepřesný a článek obsahuje i faktické chyby (MARTíNEK 1985: 28-29).

3 Honzl věnuje ve své knize Vznik moderniho ruského divadla Jevreinovovi několik stránek, na kterých poměrně nadšeně představuje českým čtenářum tuto osobnost (HONZL 1927: 48-53). Zajímavý je proto pohled 
„Scénické ztvárnění života“ (Театрализация жизни) z Jevreinovova Divadla jako takového (Театр как таковой) v překladu Danuše Kšicové.

Hlavním problémem výzkumu se stal nedostatek zdrojů. Fragmentární zmínky v českých publikacích posloužily jako odrazový můstek, bylo ale nezbytné využít zdrojů z rozličných časových i geografických oblastí - k získání ucelené představy o jeho životě - i pramenư ${ }^{4} \mathrm{k}$ budoucímu podrobnějšímu zkoumání Jevreinovovy teoretické práce. Čerpala jsem z fondů Slovanské knihovny Národní knihovny ČR, dále z knihoven Institutu slavistiky v Paříži (Institut d'études slaves) a BULACu (Bibliothèque universitaire des langues et civilisations), Francouzské národní knihovny (Bibliothèque nationale de France) a z dalších dostupných zdrojů. Informace, které se mi nepodařilo dohledat jinde, jsem čerpala z ruské Wikipedie. V české i světové literatuře se vyskytuje několik variant přepisů jména této osobnosti. V češtině se lze často setkat $\mathrm{s}$ transkripcí Jevrejnov, výjimečně se vyskytuje i možnost Jevrejinov. Osobně se přikláním k variantě Jevreinov $^{5}$ a v tomto textu budu užívat výhradně ji, prrípadné citace však budou zachovány v původní verzi.

\section{Biografické fragmenty}

Cenným zdrojem základních informací se ukázala být kniha Anny Kašinové Jevreinovové $N$. N. Jevreinov v mirovom teatre $X X$ veka. Anna Kašinová Jevreinovová se snaží, byt’ trochu schematicky, důsledně zmapovat manželovu divadelnickou činnost v emigraci, ${ }^{6}$ v tuto chvíli však není možné ověřit úplnost a přesnost uvedených údajů. K období strávenému v Rusku (tj. do roku 1925) se pak téměř nevyjadřuje, pravděpodobně proto, že se v předřrijnové době, kdy byl Jevreinov na tvůrčím vrcholu, ještě neznali. Druhým zásadním zdrojem tohoto biografického přehledu byla předposlední kapitola knihy Une saga libérale en Russie: les Evréinov, Juifs, marchands, nobles et artistes (1650-1950), publikované pod pseudonymem Dominique de Nièvre, mapující třísetletou historii rodiny Jevreinovových od poloviny 17. století až do smrti Nikolaje Jevreinova v roce 1953 . V kapitole věnované Nikolaji Jevreinovovi čerpá de Nièvre z nepublikovaných studiî7 Anny

do pozdějšího díla Základy a praxe moderního divadla, kde není Jevreinovovi v textu věnován ani řádek. Př́ičinu Honzlova postupného nezájmu hledejme v Jevreinovově emigraci z SSSR a z toho plynoucí ignoraci ze strany sovětských teoretiků umění i jejich následovníků.

4 Všechna Jevreinovova díla jsou dostupná v digitalizované podobě na http://www.teatr-lib.ru/Library/ Personal/Evreinov_Nikolay_Nikolaevich.htm.

$5 \quad \mathrm{~V}$ azbuce se toto jméno píše Евреинов, varianta Jevreinov je tedy jeho nedokonalou transliterací. Po mém soudu je však vhodnější než transkribovaná verze Jevrejnov, jelikož více odpovídá ruskému originálu a k odlišnostem ve výslovnosti nedochází. Databáze národních autorit Národní knihovny ČR tento předpoklad potvrzuje.

6 Jevreinovovi Rusko opustili v roce 1925 a většinu času prožili v Paříži.

7 De Nièvre zmiňuje dva prameny - jednak „bibliografickou montáž“ popisující Jevreinovův život v Rusku do svatby s A. Kašinovou (1879-1920) a jednak vyprávění o společném životě, nazvané $A$ l'étranger ( $V$ zahranič́), které popisuje období od svatby do konce 2. světové války (1920-1945). Z druhého jmenovaného zdroje Anna Jevreinovová čerpala při sestavování výše zmiňované publikace $N$. N. Jevreinov ve světovém divadle 20. století. 
Kašinové Jevreinovové, z jejích osobních deníků, uložených ve Francouzské národní knihovně (BNF), z Knihy o Jevreinovovi $\mathrm{V}$. Kamenského ${ }^{8}$ a z dalších zdrojů z Jevreinovovy pozůstalosti. Informace o Jevreinovovi sice oproti publikaci Jevreinovové významně doplňuje, jelikož však z velké části pocházejí ze stejného (a neobjektivního) zdroje, výše uvedená poznámka o obtížnosti ověření platí i zde. Tato malá biografie bude především souhrnem dostupných informací a částečně i spekulací z nich vyplývajících a nečiní si žádné nároky na úplnost.

\section{Dětství}

Nikolaj Nikolajevič Jevreinov se narodil v Moskvě 13. února ${ }^{9} 1879$. Po matce Valentině Petrovně de Grandmaison (де Грандмезон) zdědil francouzské předky šlechtického původu a také temperament a lásku k hudbě. I otec Nikolaj Vasiljevič, inženýr pozemních komunikací, patřil k rodině, která dokládala svůj původ až do poloviny 17. století. Vlivem otcovy služby strávil Nikolaj dětství na cestách. V dopise G. V. Švarcovi-Bostuničovi se svěřuje, že lidí měl kolem sebe spoustu, př́ítele však ani jednoho (BABENKO 2011: 7-9). De Nièvre hovoří o velmi blízkém vztahu se sestrou Natálií. ${ }^{10}$ Ten se zřejmě, kvưli sedmiletému věkovému rozdílu, rozvinul až později. ${ }^{11}$

První divadelní zážitky získal Jevreinov v Tartu. V tomto univerzitním městě, označovaném za významné kulturní centrum Estonska, nebyla nouze o události nejrůznějšího typu; odehrávala se zde regata, průvody i divadelní představení. Již ve školním věku organizoval s bratrem Vladimírem vlastní amatérská představení a projevoval prý při nich nemalý cit pro divadlo a divadelnost. Jedním z námětů byla parodie večeře s ministrem dopravy, která se u Jevreinovových uskutečnila. Ne náhodou tato událost Nikolaje zaujala - není těžké si představit, s jakou oficialitou a obřadností taková večeře musela probíhat. První prožitky z vlastní tvorby ovšem obvykle končívaly slzami autora, nebot’ mu je „kazila“ malá Natálie; z touhy připojit se k bratrům přelézala přes rampu (srolovaný koberec) na jeviště, a ničila tak jejich snahu o divadelní iluzi. Jen o několik let později v nedalekém Pskově, kam se rodina přestěhovala, získal třináctiletý gymnazista první „serióznějšíi divadelní zkušenost - jako klaun Boclaro se zúčastnil představení kočovného cirkusu. Na podzim téhož roku, poté, co byl vyloučen z gymnázia za (údajně velmi zdařilé) karikatury vlastních profesorů, byl vyslán rodinou do Petrohradu, aby zde studoval právní vědy. Na léto se ovšem vracel do Pskova, kde hned první prázdniny strávil opět u divadla. Tentokrát pod pseudonymem

8 Василий В. Каменский: Книга о Евреинове. Tato kniha není mezi mými zdroji zahrnuta z toho důvodu, že po stěhování archivu BNF není k nalezení (červenec 2014).

9 Dle gregoriánského kalendáře 25. února.

10 Jevreinovovi měli čtyři děti: Vladimira, Věru, Nikolaje a Natalii.

11 Natalia Nikolajevna Jevreinovová (1886-1942). Kvůli své přiznané homosexualitě byla Stalinovým režimem přemístěna do Lugy, kde čekala na deportaci. Nakonec jí bylo dovoleno vrátit se (v době nacistické invaze) do Petrohradu (Leningradu). Téměř tříletou blokádu provázenou hladomorem, jako mnoho dalších, nepřežila. 
Gorkin odehrál svou první „skutečnou“ roli v představení profesionálního souboru. Prázdniny 1895 a 1896, poté, co se rodina přestěhovala do Moskvy, a rodiče se rozvedli, prožil v okolí Moskvy a živil se jako kočovný hudebník.

\section{V předříjnovém Petrohradě}

Ve druhém roce svých petrohradských studií pak zahájil divadelnickou činnost i v hlavním městě. Nejprve byl aktivní v amatérském souboru studentů práv, pro nějž napsal několik her, a v dalších inscenacích také sám účinkoval. Také se začal hlouběji věnovat hudbě. V roce 1901 úspěšně, se stř́ibrnou medailí, ukončil studia práv prací Historie tělesných trestů v Rusku (История телесных наказаний в России). Bezprostředně poté nastoupil do státní správy. Zároveň se rozhodl pokračovat v dalších studiích, tentokrát ve třídě kompozice N. A. Rimského-Korsakova a A. K. Glazunova na petrohradské konzervatoři. Kromě práce a studia hrál v Novém divadle L. B. Javorské12 a současně studoval filosofii pod vedením A. I. Vvěděnského. ${ }^{13}$

V následujících letech Jevreinov vystřídal několik divadelních scén: Starodávné divadlo, Křivé zrcadlo nebo Divadlo Kommisarževské, o nichž bude řeč vzápětí. Patří pouze k nejvýznamnějším bodům na petrohradské divadelní mapě, nejsou to však jediná divadla, se kterými byl Jevreinov v kontaktu. Jeho dramata uvádělo mnoho scén, včetně těch imperátorských. Jevreinov byl, zdá se, poměrně výraznou postavou tehdejší doby. $^{14}$

V této době začal Jevreinov rozpracovávat své divadelní teorie; vytvářel první monodramata a začínal pracovat na svých teoriích o divadelnosti (Театральность). Do začátku první světové války stihl ještě podniknout několik cest po světě: navštívil západní Evropu, Řecko, Maroko, Egypt a Turecko. ${ }^{15}$ Kromě toho hodně cestoval po vlasti. Při těchto př́ležitostech byl několikrát účastníkem lidových rituálů, například tradiční svatby. Odtud de Nièvre odvozuje Jevreinovův zájem o ruské lidové divadlo a rituály s teatrálními prvky. ${ }^{16}$

12 Lidia Borisovna Javorská (1871-1920), ruská herečka. V roce 1918 emigrovala do Londýna. Jejím prvním mužem byl spisovatel a publicista, kníže V. V. Barjatinskij, druhým pak historik a žurnalista, sir F. J. Pollock.

13 Alexandr Ivanovič Vvěděnskij (1856-1925), psycholog a filozof, prezident Petrohradské filozofické společnosti (Философское общество при Петербургском университете). Pravděpodobně díky němu se Jevreinov seznámil s myšlenkami eudaimonismu.

14 Mezi jinými jmenujme Viktora Šklovského, který v několika svých dílech podává svědectví o tehdejší ruské inteligenci. O Jevreinovovi se zmiňuje mezi řečí několikrát a jeho nepř́lilš vřelé poznámky vzbuzují zvědavost. Např.: „,[Nikolaj Kulbin] věril vlivu slunečních skvrn na revoluci a čekal ji co nevidět. Věřil v genialitu Jevreinova. Tahle skrvna mu nevyšla." (ŠKLOVSKIJ 1972: 77)

15 O účelech těchto cest neznáme v tuto chvíli žádné podrobnosti. Nedá se ani říct, měly-li nějaké politické pozadí či se jednalo o čistě soukromou záležitost, nevíme ani, s kým se na svých cestách setkal.

16 Jevreinov ale nesouhlasí s názorem, že divadlo se vyvinulo z rituálu. Domnívá se, že divadelnost (těatral'nosṫ), která způsobuje naší potřebu převtělování, a je tak zodpovědná za vznik divadla jako takového, je pud preestetického charakteru (JEVREINOV 2014). 


\section{Starodávné divadlo ${ }^{17}$}

Dne 5. ledna 1907, na banketu pořádaném u příležitosti desátého výročí založení revue Divadlo a umění, ${ }^{18}$ se Jevreinov seznámil s baronem Nikolajem Vasiljevičem Drizenem. Drizen, zaujat Jevreinovovou koncepcí Starodávného divadla, které mělo za cíl rekonstruovat různé divadelní hry v intencích odpovídajícího dobového stylu a konvencí, slíbil Jevreinovovi podporu, a právě díky němu mohlo Starodávné divadlo opravdu začít pracovat.

Starodávné divadlo však fungovalo pouhé dvě sezóny. V té první, 1907/1908, se v divadle věnovali západoevropskému středověkému divadlu, v druhé, 1911/1912, pak divadlu španělského Zlatého věku. Třetí sezóna, 1914/1915, ve které se měl zájem soustředit na italskou komedii masek, se již neuskutečnila.

Podle Jevreinova (a dalších modernistů) zažívalo tehdejší divadlo úpadek pramenící z realismu. Proto tento tvưrce považoval za nutné vrátit se k předchozím epochám a v jejich divadelních zvyklostech hledat nosné prvky, v kterých by bylo možné najít východiska pro „zdivadelnění“ moderního divadla. Zde stojí za povšimnutí, že Jevreinov už tehdy nebral divadlo za způsob ztvárnění dramatické literatury, byt ranými modernisty byl soulad mezi záměrem básníka a režiséra považován za důležitý (SOLOGUB 2004). Pokládal za nezbytné původní kusy nestudovat pouze na papíre a na základě dochovaných pramenů, ale znovu inscenovat, aby byl reevokován co nejkomplexnější zážitek.

Soubor Starodávného divadla byl tvořen převážně ochotníky, studenty a herci Suvorinova divadla, výtvarně pak s divadlem spolupracovali umělci sdružení kolem Světa umění. ${ }^{19}$ Autorem emblému divadla je Ivan Bilibin. Kromě výše jmenovaných se na chodu divadla podíleli např́ílad Michail N. Burnašev, Aleksandr A. Sanin, Konstantin M. Miklaševskij a Natal'ja I. Butkovská, přičemž většina z nich kombinovala režijní činnost s výzkumnou. Kromě těchto přímých realizátorů spolupracovala s divadlem řada vědců a literátů, kteří přispívali konzultacemi dobových reálií nebo se podíleli na překladech. V inscenacích Starodávného divadla hrála významnou roli také hudba, kterou měli na starosti Aleksandr K. Glazunov a Il’ja A. Sac. Druhý zmíněný spolupracoval i se Stanislavského MCHT $^{20}$ (hudba k inscenaci Maeterlinckova Modrého ptáka), s divadlem Kommisarževské a Křivým zrcadlem. Za choreografii byl zodpovědný Michail M. Fokin.

17 V této podkapitole byl, mimo jiné zdroje, použit článek Starinnyj teatr. In Wikipedia: the free encyclopedia [online]. San Francisco (CA): Wikimedia Foundation, 2001- [cit. 2014-11-26]. Dostupné z: https:// ru.wikipedia.org/wiki/Cтаринныц_театр.

18 Театр и искусство, revue vedená A. R. Kugelem. Ten stál, společně se svou ženou, herečkou Zinaidou Cholmskou, u zrodu kabaretu Křivé zrcadlo, o němž bude řeč v následující kapitole.

19 Мир искусства, umělecké sdružení, fungující v Rusku mezi lety 1898 a 1924. U zrodu spolku stáli Aleksandr N. Benua a Sergej P. Ďagilev. Skupina vydávala stejnojmenný časopis.

20 Moskovskij chudožestvennyj teatr (MCHT), založen r. 1898 K. S. Stanislavským a Vl. Němirovičem-Dančenko. Pod tímto názvem divadlo fungovalo do roku 1919, kdy byl do názvu přidán přívlastek akaděmičeskij (MCHAT). Přes různé další modifikace jména v pozdějších letech se divadlo objevuje především pod touto zkratkou, zde je však záměrně v souvislosti s historickým kontextem použito původního označení. 
Příprava k první sezóně spočívala především ve shromaždování pramenů. Drizen navštívil západoevropské kláštery (byl v Mnichově, Norimberku i Rotenburgu), Burnašev se zase vypravil do Paříže a Kolína, kde získal materiály o historii středověkého divadla. Jevreinov zatím zveřejnil prohlášení o koncepci a úkolech Starodávného divadla, kde zdůraznil úlohu herců, kteří byli zodpovědní za „vytváření atmosféry“. Zároveň zmiňuje, že představení se mají konat jak v tradičních divadelních prostorech, tak na ulici. Během této sezóny tvůrci představili hry různých středověkých žánrů, včetně moralit a miráklo̊, posbírané na území Německa a Francie. Ve druhé uskutečněné sezóně inscenovali hry Calderóna, Tirso de Moliny, Lope de Vegy a Miguela de Cervantese.

\section{Divadlo Komissarževské}

V zimě 1908/1909 byl Jevreinov pozván do divadla Věry Fjodorovny Komissarževské, aby zaujal místo vzniknuvší vynuceným odchodem Vsevoloda E. Mejercholda. Brockett později píše: „Mejercholdův nástupce v divadle Komissarževské[,] Nikolaj Nikolajevič Jevrejnov (1879-1953)[,] byl stejně naladěný proti realismu [jako Mejerchold, pozn. JB], ale snažil se posílit hercovo místo v divadle zdůrazňováním divadelnosti a grotesky“ (BROCKETT 1999: 561-562). Tato sezóna, která se uskutečnila pod uměleckým vedením ${ }^{21}$ Jevreinova a Fjodora F. Komissarževského, bratra Věry Fjodorovny, byla však zároveň poslední sezónou divadla.

\section{Křivé zrcadlo22}

V roce 1908 vznikla v Petrohradě dvě divadla malých forem. Mejercholdovo Lukomorje $^{23}$ a Křivé zrcadlo, jehož historie je neodmyslitelně spjatá s již zmíněným A. R. Kugelem. Ten založil divadlo společně s manželkou, herečkou Zinaidou Cholmskou. Divadlo fungovalo (s přestávkou v neklidných letech občanské války 1918-1922) až do roku 1931. Po smrti Aleksandra Kugela (1928) se však divadlo ocitlo v krizi, hledalo svou tvář a cestu, kudy se dále ubírat. Po třech letech tuto marnou snahu lidé kolem divadla vzdali a činnost souboru ukončili.

V první fázi existence sdílela tato dvě výše zmíněná divadla společný prostor v paláci Jusupovových; Mejercholdovo divadlo však záhy ukončilo provoz, a Křivé zrcadlo se tak na chvíli stalo údajně jedinou kabaretní scénou tehdejšího Petrohradu. V Křivém zrcadle nebylo možné hrát častěji než jednou či dvakrát v týdnu, i proto, že v něm účinkovali herci, kteří měli povinnosti na jiných petrohradských scénách. Byl tu dán prostor i zájemcům z řad amatérů, večerní pásma byla kombinována. Zájem publika o tuto parodicko-satiric-

21 Jevreinovovi prý divadlo patřilo ve dne a Komissarževskému večer a v noci.

22 Kromě již zmíněných zdrojů čerpáno z wikipedického hesla Кривое зеркало.

23 Лукоморье. V mytologii východních Slovanů označuje toto slovo, znamenající mořský záliv, zakázané místo na kraji světa, kde roste „strom světa”, jakýsi yggdrasil, který tvoří cestu do jiných světů. Zároveň je tím zřejmě odkázáno k poezii A. S. Puškina. 
kou scénu však začal postupně upadat, v roce 1910 tak Kugel pozval na místo hlavního režiséra Nikolaje Jevreinova, který definitivně zanechal práce na ministerstvu a začal se věnovat pouze divadlu. Toto místo zastával téměř sedm let, během nichž měl možnost prakticky rozpracovat svou teorii monodramatu. Jeho působení přineslo změnu dramaturgie, z programu téměř zmizela ochotnická čísla a naopak se začal tvořit stálý profesionální soubor, což umožnilo přesun představení již na devátou večer. Během těchto sedmi let vytvořil Jevreinov v Křivém zrcadle okolo sta režií. Zkušenosti a zážitky z tohoto působení sepsal Jevreinov v knize Ve škole di̊vtipu (В школе остроумия).

\section{Válka a Velká říjnová revoluce}

První dva válečné roky trávil Jevreinov ve Finsku. ${ }^{24}$ Tuto informaci potvrzuje Šklovskij: „V květnu roku 1915 vyhrál Majakovskij šedesát pět rublů a odjel do Kuokkaly. Obědval střídavě u Čukovského, Jevreinova, Repina.“ (ŠKLOVSKIJ 1972: 163) Kromě toho existuje několik Jevreinových portrétů z tohoto roku: Jeden od Majakovského, lokalizovaný do Finska, druhý od Ilji Repina a třetí od Jurije Anněnkova, taktéž z roku 1915. Anněnkov je v umístění nejkonkrétnější, zmiňuje přímo Kuokkalu. ${ }^{25}$

Tato informace je pro nás přínosná z toho důvodu, že dává lepší představu o tom, s kým se Jevreinov stýkal a kdo ho mohl potenciálně ovlivňovat. Kromě výše zmíněných víme o Nikolaji Kulbinovi ${ }^{26}$ s dcerou, jež de Nièvre dokonce označuje za „Jevreinovovu druhou rodinu“ a který byl, podle Šklovského, taktéž v Kuokkale, ${ }^{27}$ a také o Sergeji Ejzenštejnovi. ${ }^{28}$

\section{Po převratu}

Po říjnovém státním převratu opouští Jevreinov Petrohrad a odjíždí na Kavkaz, kde pořádá přednášky a píše hry - během této doby napsal hru Co je nejhlavnějši (Camoe главное), která ho proslavila po celém světě. ${ }^{29} \mathrm{Z}$ Kavkazu se vrací až o tři roky později,

24 Finská Kuokkala se nachází ani ne 50 kilometrů od Petrohradu, tudíž je možné si představit, že v době, kdy zde pobýval, byl zároveň schopen dostát svým divadelním povinnostem v Petrohradě.

25 Kuokkala, dnešní Repino, je městečko na rusko-finských hranicích. Př́ísně vzato bylo v době, o níž píšeme, součástí Ruska (ovšem i s celým Finskem). Po vyhlášení samostatnosti (1917) se Kuokkala stala finským městem, Rusku připadla v druhé polovině 40. let, kdy také byla přejmenovaná na Repino, podle Ilji Repina, jehož pozoruhodný dům (tzv. Penáty) s ateliérem stojí na kraji města a v jehož zahradě je Repin pohřben.

26 Nikolaj Ivanovič Kulbin (1868-1917), vzděláním lékař, znám jako malír a hudebník, též divadelní teoretik.

27 „Jsou tu osadníci. Nikolaj Ivanovič Kulbin má domek pronajatý, Nikolaj Jevreinov rovněž.“ (ŠKLOVSKIJ 1972: 153)

28 „Divadla a lidi kolem nevídal Sergej Michajlovič už jenom ve snu. Chodil k Jevreinovovi a znal se s ním. Nikolaj Jevreinov, stárnoucí krasavec, mu ukázal čtvery desky přecpané vystřiženými recenzemi o jeho režijní práci. Nikolaj Jevreinov měl rád slávu. Sergej Ejzenštejn divadlo.“ (ŠKLOVSKIJ 1983: 50)

29 V Čechách byla uváděna ve Stavovském divadle v režii Vojty Nováka (1923), později byla inscenována i Jindřichem Honzlem v Brně (1930). 
v roce 1920. De Nièvre uvádí, že podle Davida Burljuka neměla na Jevreinova revoluce vliv a se zápalem sobě vlastním pokračoval v divadelní činnosti.

Po skončení občanské války se mnoho umělců vrací do Petrohradu. Vznikají nová divadla, mezi nimi Divadlo komické opery (Театр комической оперы) Konstantina Mardžanova nebo Volná komedie (Вольная комедия) Nikolaje Vasiljeviče Petrova. Právě v posledně jmenovaném byla ve světové premiéře uvedena Jevreinovova hra Co je nejhlavnější.

V tomto období se také rozvíjí žánr agitky. V určitém smyslu se dá za jeho vrchol považovat masová inscenace Dobyti Zimniho paláce, nastudovaná u příležitosti tříletého výročí říjnového převratu. Jevreinov byl hlavním režisérem, asistenty se stali A. R. Kugel, A. Petrov, G. Děržavin a Ju. Anněnkov, který byl zároveň hlavním výtvarníkem.

Po návratu do Petrohradu Nikolaj Jevreinov vedl také divadelní kurzy a přednášel. Na nich se seznámil s jednou z frekventantek, se kterou se brzy poté oženil. Ta ho doprovázela až do konce života a právě ona má velkou zásluhu na dokumentaci jeho aktivit i pozdějším odborném výzkumu, o čemž bude řeč později. Poslední roky, které prožili v Rusku, byly naplněny Jevreinovovou publikační činností. Kromě toho opět, tentokrát již s doprovodem, cestoval na Kavkaz a několik měsíců strávil cestou do Evropy.

Anna Kašinová Jevreinovová vzpomíná, že jednoho dne přišel telegram, v němž Mejerchold Jevreinovovi nabídl Druhé (sám si bera První) divadlo RSFSR v Moskvě, byt a zajištění stěhování nábytku a knihovny. Jevreinov však údajně do Moskvy nechtěl. To, že měl s Mejercholdem dlouhodobé osobní neshody, odmítnutí nabídky jen usnadnilo.

\section{Vemigraci}

Davová produkce Dobyti Zimniho paláce se zdá být poslední Jevreinovovou divadelní aktivitou v Rusku, která vzbudila větší ohlas. Z pramenů jsem nevyčetla přesný důvod Jevreinovovy následné emigrace, dá se ale předpokládat, že jedním z důvodů byl nástup Stalina k moci. To naznačuje drobná poznámka z knihy Anny Jevreinovové $N$. $N$. Jevreinov ve světovém divadle 20. století: „Toto všechno [se] samozřejmě [událo] v předstalinovském Rusku, v době Stalina už pro Jevreinova ve vlasti nebylo místa. Budeme doufat, že se destalinizace dotkne i jeho her, které byly až do počátku třicátých let úspěšně přijímány i tam. " ${ }^{30}$ (KACHINA JEVREINOVA 1964: 102)

Z Petrohradu odjeli Jevreinovovi na konci ledna 1925. Ačkoliv měli v pasech uvedenu půlroční cestu, mezi jejich přáteli, kteří se s nimi přišli na nádraží rozloučit, bylo veřejným tajemstvím, že se tato cesta pravděpodobně protáhne. Jevreinovová popisuje zážitky z cesty poměrně podrobně a barvitě, zde však není většího důvodu zacházet do podrobností. Důležité je, že se i přes kontroly ze strany agentů GPU ${ }^{31}$ Jevreinovovi dostali do Rigy a odtamtud do Polska. Ve Varšavě se sešli s okleštěným souborem Křivého zrcadla - některým

30 [překl. JB], v orig. znění: „Все это, конечно, в до-сталинской России, при Сталине Евреинову уже не нашлось места на родине. Будем надеяться, что десталинизация доберется и до его пьес, шедиих с успехом и на его родине до начала тридиатых годов."

31 Gosudarstvennoe političeskoe upravlenie - ruská tajná služba, předchůdce dnešní KGB. 
představitelům nebylo povoleno přejet hranice. Právě opětovné angažmá Jevreinova na pozici režiséra posloužilo jako záminka odjezdu z vlasti. Přes další zastávky se Jevreinovovi dostali do Paříže, kde se, až na roční pobyt v Americe, trvale usadili.

\section{Závěrem}

Jevreinov žil až do roku 1953 v pařížské Rue de Boileau 7, kde v září téhož roku zemřel. Divadlu se věnoval i v emigraci, a i když dále režíroval, zásadní teoretickou práci už, zdá se, nevytvořil. Také při ostatních činnostech čerpal především ze zkušeností ruských - přednášel o ruském divadle, psal vzpomínky, studie o ruském divadelnictví. Sergej Makovskij cituje S. Volkonského, který napsal, že Jevreinov byl v zahraničí považován za ,jediného ruského dramatika, který patří současnému divadlu, současnému světovému divadlu“ (MAKOVSKIJ 2000: 358). ${ }^{32}$ Svými hrami se opravdu proslavil celosvětově. Jacques Copeau zrežíroval jeho Veselou smrt (Веселая смерть), ${ }^{33}$ Pirandello zase Cо je nejhlavnější. Druhá zmíněná hra byla přeložena do osmnácti jazyků a hrána v šestadvaceti zemích, na základě inspirace touto dramatickou předlohou byl dokonce natočen francouzsko-italský film La comédie du bonheur.

V dnešní době se o Jevreinovovi „obecně ví“, že je autorem konceptu divadelnosti. Zdá se však, že tato divadelnost je někdy nesprávně chápána jako divadelní stylizace. Ačkoliv byl v průběhu minulého půlstoletí o Jevreinovovu tvorbu několikrát projeven zájem, kromě posledních let zřejmě nikdy nebyl prováděn systematický výzkum. O manželův odkaz ve Francii důsledně pečovala Anna Jevreinovová, z jejíhož popudu se odehrálo kolokvium ke stému výročí narození autora. Byly proneseny příspěvky o mnoha aspektech Jevreinovovy tvorby (namátkou např́iklad Jevreinov a hudba, Jevreinov a politické divadlo dvacátých let nebo Teatralita u Jevreinova a ruských futuristů), všechny vyšly o dva roky později (1981) v rámci Revue des Études Slaves v čísle nazvaném Nicolas Evreinov: L'Apôtre russe de la théâtralité. Z přispěvatelů stojí za zmínku obzvlášt práce americké badatelky Sharon M. Carnicke, která Jevreinovu konceptu teatrality později věnovala knihu The theatrical instinct: Nikolai Evreinov and the Russian theatre of the early twentieth century, vydanou v roce 1989 v New Yorku. V následujících letech vyšly ještě tři pozoruhodné publikace, z nichž je patrné, že i v Rusku se dlouhá léta opomíjenému divadelníkovi snad dostane zasloužené pozornosti. V roce 1992 (2. vydání vyšlo v roce 2011) představilo nakladatelství Uralské univerzity knihu Arlekin i P’jero, dvojbiografii Nikolaje Jevreinova a Alexandra Vertinského z pera Vladimira G. Babenka. Chronologicky dalším dílem zasvěceným Jevreinovovi je publikace Dominique de Nièvre, zmiňovaná v úvodu. Motivace autora není vědecká, ale osobní (vazby na rodinu Jevreinovových), tudíž se nedá předpokládat, že by výzkum o Nikolaji Jevreinovovi prohluboval. Zatím nejmladší studií je disertační práce s názvem Nikolaj Jevreinov v kul'turnoj žizni Rossii i zarubežjja, kterou v roce 2013 zveřejnil absolvent oboru historie Petrohradské

32 „[...] единственным русским драматургом, принадлежащим, современному “ театру, современному мировому театру."

33 Veselou smrt v Čechách poprvé uvedl Jiří Frejka v Legii Malých v Praze (1924). 
státní univerzity Vitalij J. Ryženkov. Všechny tři posledně jmenované knihy mají charakter biografie, vedený výzkum tedy zatím nepokročil ke zkoumání skutečného významu Jevreinovových teorií a divadelního působení obecně, ale poskytují mu kvalitní podhoubí, které bych tímto shrnutím ráda nabídla pozornosti českých teatrologů.

\section{Bibliografie}

BABENKO, Vladimir G. 2011. Arlekin i P'jero [Harlequin and Pierrot]. Jekatěrinburg: Izdatel'stvo Ural'skogo universiteta, 2011.

BROCKETT, Oscar Gross. 1999. Dějiny divadla [History of Theatre]. Praha: Lidové noviny, 1999.

HONZL, Jindřich. 1927. Vznik ruského moderního divadla [Origins of Modern Russian Theatre]. In Alexandr Tairov. Odpoutané divadlo [Theatre Unbound]. Praha: Orbis, 1927.

HONZL, Jindřich. 1963. Základy a praxe moderního divadla [Principles and Praxis of the Modern Theatre]. Praha: Orbis, 1963.

JEVREJNOV, Nikolaj. 2014. Scénické ztvárnění života. Ex cathedra [Staging the Life. Ex Cathedra]. Theatralia 17: 1 (2014): 119-148.

KACHINA JEVREINOVA, Anna Aleksandrovna. 1964. N. N. Jevreinov v mirovom teatre XX veka. Paříž, 1964.

Krivoe zerkalo (teatr) [Crooked Mirror (the Theatre)]. In Wikipedia: the free encyclopedia [online]. San Francisco (CA): Wikimedia Foundation, 2001 [cit. 2014-12-01]. Dostupné z: https:// ru.wikipedia.org/wiki/Кривое_зеркало_(театр).

MARTÍNEK, Karel. 1966. Prameny ruské divadelni moderny [Sources of the Russian Modernism]. Praha: Svět sovětů, 1966.

MARTÍNEK, Karel. 1967. Dějiny sovětského divadla (1917-1945) [History of the Soviet Theatre (1917-1945)]. Praha: Orbis, 1967.

MARTÍNEK, Karel. 1985. Portréty představiteli ruské předrevolučni moderny, sovětské divadelni avantgardy a vybraných osobností dramatického uměni v SSSR [Portraits of the Russian Pre-Revolution Modernists, Soviet Theatre Avant-Garde, and Other Theatre Personalities of the Soviet Union]. Praha: Divadelní ústav, 1985.

NIÈVRE, Dominique de. 2004. Une saga libérale en Russie: les Evréinov, Juifs, marchands, nobles et artistes (1650-1950). Paris: L'Harmattan, 2004.

OSOLSOBĚ, Ivo. 2003. Ostenze, hra, jazyk [Ostension, Play and Language]. Brno: Host, 2003.

SOLOGUB, Fjodor. 2004. Divadlo jediné vůle [Theatre of the Only Mind]. In Pavel Klein a Simona Koryčánková (edd.). Manifesty ruského symbolismu III.: Divadlo [Manifests of the Russian Symbolism III: Theatre]. Brno: Masarykova univerzita, 2004.

Starinnyj teatr [The Ancient Theatre]. In Wikipedia: the free encyclopedia [online]. San Francisco (CA): Wikimedia Foundation, 2001 [cit. 2014-11-26]. Dostupné z: https://ru.wikipedia.org/ wiki/Cтаринный_mеатр.

ŠKLOVSKIJ, Viktor Borisovič. 1983. Ejzenštejn. Praha: Odeon, 1983.

ŠKLOVSKIJ, Viktor Borisovič. 1972. Vzpominky na vzpominky [Memories of Memories]. Praha: Československý spisovatel, 1972. 


\section{Summary}

\section{Life of Nikolai Evreinov}

Biography of Russian director, playwright and art theoretician Nikolai Nikolayevich Evreinov (1879, Moscow - 1953, Paris) based on Russian and French sources covers his theatre activities from the start till 1925, the year of his emigration. Despite being one of the most important personalities of Russian Silver Age, Evreinov was erased from the official records after he had left Russia, his memory being doomed to oblivion. However, the current research on his theatre works suggests his contribution to the theatre might be significantly reevaluated and reappreciated in the future. The given paper draws on these new findings, presenting noteworthy information on Evreinov's life as yet often unknown to the Czech scholarly public.

\section{Klíčová slova}

Jevreinov, Stříbrný věk, Křivé zrcadlo, Starodávné divadlo, Dobyti Zimního paláce, Divadlo Komissarževské, divadelnost, teatralizace, zdivadelnění, ruská emigrace

\section{Keywords}

Jevreinov, Russian Silver Age, Krivoe zerkalo (Crooked Mirror), Starinnyj těatr (Ancient Theatre), Dobyti zimniho paláce (Storming of the Winter Palace), Komissarzhevskaya Theatre, theatricality, performativity, performance, Russian emigration

DOI: $10.5817 /$ TY2016-1-10

Jana Bartůňková absolvovala bakalářské studium na Katedře divadelních studií Masarykovy univerzity. V současnosti studuje rusistiku v magisterském programu na Université Paris - Sorbonne. Její akademický zájem směřuje k umění ruského Stříbrného věku. Produkčně spolupracuje s Janem Nebeským a Studiem Damúza. Je členkou dramaturgické rady Festivalu francouzského divadla Sněz tu žábu/Mange ta grenouille. Kontakt: janabartunkova@gmail.com.

Jana Bartůňková received her BA degree at the Department of Theatre Studies, Masaryk University (Brno, CZ) in 2015. She is currently studying for getting MA degree in Russian Studies at the Paris -Sorbonne University. She has been interested in the era of Russian Silver Age; has been cooperating with director Jan Nebeský and Studio Damúza as a manager; has been a member of the dramaturgical board of the French Theatre Sněz tu žábu/Mange ta grenouille. Email: janabartunkova@gmail.com. 